\title{
Pengalaman hidup kami "lansia" aset berharga negara (kajian gerontologi di Malang)
}

\author{
Aulia Pandora Yunita, Gusti Rajendra, Novitri Yanu Bauty Argono, Luhung Achmad \\ Perguna* \\ Universitas Negeri Malang, Jl. Semarang No. 5 Malang, Jawa Timur, Indonesia \\ *Penulis korespondensi, Surel: luhung.fis@um.ac.id
}

Paper received: 03-01-2021; revised: 15-01-2021; accepted: 30-01-2021

\begin{abstract}
Abstrak
Indonesia masuk dalam periode bonus demografi beberapa tahun kedepan. Adanya dampak positif yang akan terjadi adalah penduduk dalam usia produktif yang memiliki jumlah lebih banyak daripada usia tidak produktif yang dapat memacu peningkatan dalam aspek ekonomi ini akan membawa dampak yang sangat menghawatirkan, yakni akan meningkatnya pula penduduk lanjut usia di Indonesia beberapa tahun kemudian. Menjadi beban atau aset bagi negara atas meningkatnya jumlah penduduk lansia ini akan tergantung pada bagaimana kita sebagai generasi muda menyikapinya. Malang merupakan kota dengan jumlah penduduk lansia yang cukup tinggi saat ini namun kesadaran masyarakat terutama pemerintah akan pentingnya mencegah permasalahan yang akan mengancam dimasa depan maka pemerintah mengantisipasinya dengan menerapkan konsep Kota Ramah Lansia. Data dikumpulkan dengan analisis studi dokumen, pengamatan dan wawancara mendalam. Dengan dianalisis menggunakan pendekatan kualitatif deskriptif. Teori yang digunakan dalam tulisan ini adalah teori Kependudukan oleh Karl Marx dan Fried Engels. Teori Kependudukan digunakan dalam tulisan ini untuk mengkaji mengenai gerontologi atas tingginya lansia di Kota Malang dan tingginya tingkat pertumbuhan penduduk lansia yang dapat diperdayakan melalui pengelolahan Pondok Lansia di Kota Malang seperti sekarang ini. Hasil dalam tulisan ini adalah ada beberapa program dan kebijakan dari pemerintah dan yayasan ramah lansia di Malang yang memiliki tujuan terwujudnya kenyamanan secara fisik dan psikologis para lansia ini di Kota Malang agar tetap produktif dan berperan dalam pembangunan nasional. Tingginya angka penduduk dalam usia lanjut tidak akan menjadi beban dalam keluarga, masyarakat, bahkan negara jika mereka diberdayakan dan diperlakukan dengan baik. Pengalaman, kearifan, jaringan, dan kreatifitas mereka dalam bertindak dan berfikir menjadi kelebihan yang akan menjadi aset berharga bagi lingkungan mereka dan juga bagi pembangunan nasional. Kelebihan yang sudah ada dalam diri mereka dapat diwariskan pada generasi muda untuk menghasilkan sumber daya manusia yang lebih baik untuk bekal di masa depan. Sehingga dimasa yang akan datang dan masa sekarang para lansia akan tetap produktif dan berperan dalam pembangunan.
\end{abstract}

Kata kunci: pondok lansia; aset pembangunan; masyarakat.

\section{Pendahuluan}

Periode bonus demografi (demographic dividend) merupakan kondisi dimana terjadinya transisi demografis yang ditandai dengan kenaikan dua kali lipat jumlah penduduk produktif bekerja (15-60 tahun) melebihi jumlah penduduk yang tidak dalam usia produktif (di atas 60 tahun) dan dapat memacu investasi dan pertumbuhan ekonomi. Sudah tidak menjadi rahasia lagi jika Indonesia akan masuk ke dalam periode tersebut beberapa tahun kedepan. Adanya dampak positif dengan penduduk dalam usia produktif yang memiliki jumlah lebih banyak daripada usia tidak produktif yang dapat memacu peningkatan dalam aspek ekonomi ini akan membawa dampak yang sangat menghawatirkan, yakni akan meningkatnya pula penduduk lanjut usia di Indonesia. 
Pernyataan akan hadirnya bonus demografi tersebut diperkuat dengan adanya data dari Badan Pusat Statistik (BPS) berdasarkan sensus penduduk yang terakhir dilakukan pada tahun 2010 bahwa penduduk dengan usia lansia berjumlah 23 juta (10\%). Angka tersebut menurut Bappenas masih akan bertambah dan diestimasikan pada tahun 2020 jumlah Indonesia akan menjadi sekitar 35 juta jiwa dengan usia harapan hidup mencapai 73,3 tahun.

Usia harapan hidup (UHH) yang semakin meningkat di Indonesia serta menurunnya tingkat fertilitas berdampak pada laju pertumbuhan penduduk lanjut usia secara cepat. Berdasarkan pertumbuhan lansia di Indonesiia sejak tahun 1980-2020 diperkirakan mencapai angka 11,34\% dengan perbandingan penduduk lansia melebihi 7\% sehingga Idonesia termasuk ke dalam negara dengan struktur tua (ageing population). Stuktur seperti ini termasuk dalam salah satu indikator keberhasilan pembangunan nasional maupun global. Hal ini membuktikan bahwa adanya perbaikan kualitas dalam kesehatan dan kondisi sosial masyarakat semakin meningkat.

Meningkatnya lansia merupakan indikator keberhasilan pembangunan, namun disisi lain hal ini juga akan menimbulkan berbagai masalah yang berkaitan dengan kondisi ekonomi, sosial, jasmani, dan juga rohaninya bagi penduduk lanjut usia. Sehingga jika permasalahan ini tidak segera diatasi dengan tepat maka akan mengakibatkan permasalahan nasional. Maka untuk mengatasinya lansia perlu mendapatkan perhatian dari berbagai pihak agar mereka dapat ikut berperan dalam pembangunan nasional dan tidak menjadi beban melalui kebijakan dan program yang dibuat pemerintah. Dalam pasal 55 UU RI No.30 tahun 2008 disebutkan bahwa pemenuhan hak lansia meliputi: (1) pelayanan keagamaan dan mental spriritual; (2) pelayanan kesehatan; (3) pelayanan kesempatan kerja; (4) pelayanan pendidikan dan pelatihan; (4) kemudahan dalam menggunakan fasilitas, sarana, dan prasarana umum; (6) kemudahan dalam layanan bantuan hukum; (7) perlindungan sosial, dan (8) bantuan sosial. Tantangan pembangunan seiring meningkatnya lansia di Indonesia, khususnyadi kota Malang ini akan menimbulka tingginya biaya kesehatan. Sudah berkurangnya fungsi dan sikap para lansia ini mengakibatkan pengaruh yang signifikan terhadap pemenuhan kebutuhan mereka sehari-hari mereka secara mandiri (Turana, 2013).

Meningkatnya Usia Harapan Hidup (UHH) juga tidak terlepas dari peran pemerintah dan juga dari pihak swasta lainnya yang turut andil dalam menangani masalah tingginya populasi lansia. Beberapa lembaga dan yayasan ramah lansia di kota Malang seperti salah satunya pondok lansia yang terletak pada Jl. Lasda Adi Sucipti Gg 22/A No. 30 di Kota Malang yang juga turut berperan penting pada kelangsungan hidup lansia kota Malang. Pondok lansia merupakan salah satu tempat dimana hal ini menunjukkan bahwa lansia pun dapat menjadi berarti. Dalam pondok lansia, para lansia tersebut dirawat serta diberikan pelatihan-pelatihan sederhana sehingga para lansia tersebut bisa memiliki ketrampilan untuk sekedar hobi mengisi kekosongan waktu mereka. Dalam penelitian ini penulis ingin menunjukkan bahwa menjadi lansia merupakan sebuah beban, mereka merupakan sebuah aset dan mereka masih dapat berkembang sesui dengan usia mereka. Penelitian ini merupakan penelitian literatur, dimana data yang didapatkan berasal dari penelitian serupa yang telah dilakukan, namun peneliti juga melakukan observasi dan wawancara sedehana pada pengelola Pondok Lansia kota Malang.

Tanpa mengabaikan keterkaitan diantara satu dengan lainnya maka dalam hal ini penulis ingin fokus pada kajian gerontologi masyarakat dalam menangani penduduk lanjut 
usia yang semakin meningkat di kota Malang. Dengan mengguakan teori Kependudukan oleh Karl Marx dan Fried Engels untuk mengkaji mengenai gerontologi atas tingginya lansia di Kota Malang. Masalah penelitian ini adalah bagaimana tingginya tingkat pertumbuhan penduduk lansia dapat diperdayakan melalui pengelolahan Pondok Lansia di Kota Malang. Sejalan dengan masalah penelitian tersebut, tulisan ini bertujuan untuk menjelaskan tingginya tingkat pertumbuhan penduduk lansia yang dapat diperdayakan melalui pengelolahan Pondok Lansia di Kota Malang seperti sekarang ini. Berdasarkan paparan rumusan masalah dan latar belakang yang sudah disusun, maka tujuan dari penelitian ini adalah menjelaskan tentang tingginya tingkat pertumbuhan penduduk lansia yang dapat diperdayakan melalui pengelolahan Pondok Lansia di Kota Malang seperti sekarang ini.

\section{Metode}

Kajian ini menekankan pada kajian Gerontologi pada tingginya tingkat pertumbuhan penduduk lansia yang dapat diperdayakan melalui pengelolahan Pondok Lansia di Kota Malang. Penelitian ini menggunakan pendekatan kualitatif. Alasan digunakannya pendekatan penelitian ini adalah agar konteks penelitian dapat dipahami secara naturlistik, melalui proses sehingga membutuhkan pengamatan yang mendalam dan pengakajian penelitian sebagai instrumen. (Marshall, Rossman, 1989)

Penentuan subjek mengacu pada status khusus seperti peran subjek dalam masyarakat, kedekatan dengan situasi, dan memiliki sejumlah informasi yang bisa dipertanggungjawabkan yang bisa dipercaya sebagai sumber data (Sutopo, 1988). Subjek ditentukan secara snowball sampling dengan meminta subjek sebelumnya menunjuk orang lain yang dapat dijadikan subjek berikutnya (Bogdan, Biklen, 1982).

Metode pengumpulan data dengan wawancara mendalam, observasi, dan studi dokumentasi. Wawancara mendalam digunakan untuk mengumpulkan informasi semaksimal mungkin secara personal dengan bertatap muka langsung dengan informan. Peneliti berusaha menggunakan pertanyaan-pertanyaan mendalam dengan tata urutan berbentuk cerobong. Studi dokumentasi dilakukan dengan mengumpulkan sejumlah bahan tertulis tentang statistik tingginya populasi lansia di Malang. Teknik analisis dilakukan dengan triangulasi sumber data, metode, dan teori yang ada. Peneliti menggunakan informan riview untuk menguji keabsahan informasi yang diterima. Temuan lapangan diaudit, didiskusikan dengan sejawat yang dipandang menguasai penelitian kualitatif dan berpengaruh dalam pengelolaan Pondok Lansia di Kota Malang

\section{Hasil dan Pembahasan}

Tua atau penuaan merupakan suatu kondisi dalam proses alami manusia mengalami perubahan secara fisik, mental, dan juga sosial sebagai akibat bertambahnya usia. Seorang ahli gerontologi mngatakan bahwa perubahan yang terjadi pada kulit kulit, otot dan tulang, dan sistem syaraf merupakan penurunan yang umum terjadi diusia lanjut (Fitzpattrick, 2002). Kondisi ini dapat dilihat dari beberapa perubahan yang terjadi, antara lain: (1) Adanya perubahan yang terlihat pada penampilan wajah, kulit, dan tangan, (2) Adanya perubahan yang terlihat pada tubuh seperti perubahan sistem syaraf, otak, dan organ dalam lainnya, (3) Adanya perubahan dalam fungsi panca indera (penglihatan, pendengaran, perasa, dan penciuman, (4) Dan adanya perubahan dalam penurunan sistem motorik yang berkurang seperti kekuatan, kecepatan, dan keterampilan. 
Perubahan-perubahan yang terjadi ini akan sangat berpengaruh pada aktivitas mereka terutama dalam aspek sosial ekonomi. Disisi lain hal ini juga akan menimbulkan keluhankeluhan kesehatan seperti lebih sering kelelahan, penyusutan tulang dan otot, rematik, serta seringnya nyeri sendi. Mobilitas yang mulai menurun serta berkurangnya orientasi ruang gerak dan lambatnya dalam bereaksi.

Dalam pandangan aspek psikologis, manusia yang menua ini selalu berhadapan dengan rasa sepi di masyarakat. Mereka menganggap bahwa masyarakat sudah terlalu individualis untuk menganggap lansia. Hal ini akan membuat keadaan semakin buruk jika mereka dalam posisi ekonomi yang kurang baik, lngkungan yang kumuh, dan sosial yang kurang mendukung. Mereka akan mudah mengalami stress, depresi, bahkan dapat mengalami schizophrenia. Sehingga mereka akan membutuhkan lingkungan sebagai tempat mereka yang didalamnya dapat memberikan mereka rasa nyaman dan aman secara fisik dan psikisnya.

Walaupun dalam tubuh mereka mengalami penurunan secara fisik namun, mereka lebih memiliki kelebihan dalam pengalaman dan jaringan. Seperti yang kita ketahui bahwa saat ini masih banyak sekali kesalahan yang dilakukan dalam merawat lansia ini seperti memasukkan mereka ke dalam panti jompo yang secara fisik memisahkan mereka dengan keluarganya dan lingkungan sosialnya. Keadaan ini masih dianggap sesuatu yang benar dilakukan padahal mereka di dalam panti membuat mereka merasa lebih kesepian dan secara psikis mereka akan cepat mengalami stress.

Pengalaman dan jaringan mereka dalam banyak hal ini bisa dikembangkan dan diperdayakan yang akan menumbuhkan dan akan menjadi aset berharga bagi komunitas, keluarga, bahkan negara dalam aspek sosial ekonomi dalam pembangunan. Namun, pemberdayaan yang dilakukan ini harus tetap memperhatikan fungsi, kearifan, pengetahuan, keahlian, keterampialn, usia, dan fisik agar terlaksananya taraf kesejahteraan sosial bagi penduduk lanjut usia.

Menurut MIPAA (deklarasi kelanjutusiaan) ada 3 pilar dalam menjadi kelanjutusiaan, yaitu: (1) partisiasi penduduk lansia dalam pembangunan negara; (2) peningkatan kualitas layanan kesehatan dan sosial; dan (3) lingkungan yang mendukung lansia atau dikenal dengan istilah penuaan aktif. Sehingga Dokumen Ramah Lingkungan adalah gerakan di berbagai kota yang ada di setiap negara dalam mendukung lingkungan ramah lansia. Adapun kota yang ramah lansia terdiri dari 5 aspek, antara lain: (1) kawasan hunian dan rumah ramah lansia; (2) fasilitas dan infrastruktur yang ramah lansia agar mendorong kelanjutusiaan aktif; (3) transportasi dan infrastruktur yang ramah lansia; (4) fasilitas publik taman dan hiburan yang ramah usia termasuk lansia; dan (5) diskon khusus untuk transportasi, makan, sandang papan yang ramah lansia (Nugroho,2013).

Seperti yang sudah kita bahas di latar belakang dalam tulisan ini bahwa WHO memperkirakan Indonesia akan mengalami peningkatan jumlah lansia di tahun 2015 sebesar $41,4 \%$ yang sehingga pemerintah meminta agar kota ramah lansia ini segera diwujudkan. Pada dasarnya kota ramah lingkungan ini merupakan salah satu cara mengantisipasi laju pertumbuhan lansia di Indonesia yanga akan memuncak di tahun 2035. Jika hal ini tidak segera diatasi maka akan menjadi beban dalam berbagai aspek terutama aspek sosial ekonomi dalam pembangunan nasional. Sehingga sebelum itu terjadi maka lansia perlu diberi bekal aktivitas untuk dapat berperan dalam pembangunan yang lebih produktif. Ada beberapa syarat yang harus dipenuhi untuk dapat menjadi kota ramah lansia, antara lain: (1) kota harus memiliki 
seperangkat peraturan yang mengatur tentang lansia; (2) memiliki pemimpin daerah yang berkomitmen dan berkepedulian terhadap jasa; (3) memiliki metode dokumen yang ramah lansia seperti yang ada dalam ketentuan WHO yang disesuaikan dengan keadaan daerah yang bersangkutan; dan (4) fasilitas yang ramah. Dengan adanya program kota ramah lansia ini juga akan menimbulkan rasa nyaman secara fisik dan psikis bagi para lansia dalam berbagai hal.

Malang merupakan salah satu kota dari berbagai kota besar di Indonesia yang didaulat sebagai Best Practice di tahun 2030 dalam pengaplikasian kota ramah lansia. Menurut data BPS kota Malang tahun 2014 lansia di kota Malang berjumlah 74.883 jiwa dengan pembagian lansia perempuan 41.235 jiwa dan lansia laki-laki 33.648 jiwa dari jumlah keseluruhan penduduk di kota malang sebanyak 845.973 jiwa. Kota malang sendiri memiliki beberapa pelayanan khusus untuk penduduk usia lanjut seperti adanya loket khusus lansia di kantor pelayanan publik. Tidak hanya itu, DPRD Kabupaten Malang mulai merancang peraturan daerah (perda) terkait masyarakat lanjut usia (beritajatim.com). Yayasan Gerontologi Abiyoso merupakan salah satu yayasan yang berkegiatan membina lansia bentukan Lembaga Swadaya Masyarakat (LSM). Yayasan Gerontologi Abiyoso ini sudah menyebar di berbagai kota di Indonesia seperti Surabaya, Madiun, Pasuruan, Sidoarjo, dan beberapa kota lainnya termasuk di kota Malang

Yayasan Gerontologi Abisono Kota Malang yang diketuai oleh Prof. Dr. Dr. Djanggan Sargowo, Sp.Pd ini adalah salah satu yayasan yang menaungi penduduk lansia dengan menumbuhkan semangat hidup diusia mereka untuk tetap produktif menjalani kegiatan sesuai dengan kemampuan mereka (mediacenter.malangkota.co.id). Ada salah satu lagi organisasi yang menaungi penduduk lansia ini di kota Malang yaitu Organisasi Karang Weda. Organisasi ini mewadahi para lansia untuk dapat berkumpul, berkomunikasi, menyalurkan bakat dan pengalamannya serta berbagi bersama dengan lansia lainnya (lansia.com).

Temuan penelitian ini adalah bahwa tidak hanya Yayasan Gerontologi Abisono Kota Malang yang membantu lansia untuk dapat berdaya di usianya namun juga ada Pondok Lansia Al- Ishlah. Pondok Lansia ini terletak di jalan Lasda Sucipto Gg. 22 / A No. 30 Kota Malang. Lokasinya berada dekat dengan perempatan Blimbing, jalan menuju Bandara Abdurrahman Saleh, Malang. Pondok tersebut didirikan oleh Bapak Moch. Aidi dan istrinya Hj. Siti Rodiyah, namun kini keduannya telah meninggal dunia. Yayasan tersebut berakte notaries no. 13/1989 dan mengelola yatim piatu putrid pada tahun 1989 dan putra pada tahun 1997 sedangkan pondok lansia baru didirakan pada tahun 2010. Pondok Lansia ini diberi nama Al-IShlah dan pada pembukaannya diresmikan oleh Wagub Jatim Saifulloh Yusuf pada tanggal 21 Desember 2009.

Bentuk pengelolaan organisasniya sama seperti pada umumnya, yayasan ini diketuai oleh Bapak Mahfudz dan Bapak Nur sebagai rekan yang membantu beliau disana juga terdapat beberapa perawat yang dengan sabar mengurus para lansia. Ada 4 perawat dan semuanya bekerja berdasarkan pembagian shift. Biasanya 2 perawat mengurus dari jam 6 pagi sampai jam 6 malam dan setelah itu ganti oleh 2 perawat lainnya hal ini dilakukan secara bergantian setiap harinya. Pondok lansia ini memiliki kapasitas untuk 28 orang lansia. Biasanya yang diterima adalah lansia berumur 60 tahun keatas namun jika pada kondisi tertentu usia 55 tahun juga diperbolehkan. Dalam satu kamar terdapat tiga ranjang namun yang di pakai hanya 2 ranjang saja setiap kamar, hal ini dilakukan karna jika 3 orang dalam satu kamar ditakutkan 
terlalu penuh. Di dalam kamar juga terdapat satu kamar mandi dan kursi roda, kamar mereka juga saling berhadapan seperti kos-kosan namun dengan ukuran yang lebih luas.

Temuan penelitian selanjutnya adalah bawa di Pondok lansia ini hanya di khususkan lansia wanita saja. Hal ini dikarenakan perempuan dalam uasia lansia tergolong dalam kelompok yang rentan dan sering sekali mengalami multi diskriminasi, marjinalisasi, sub ordinasi, stereotip, dan juga penelantaran yang semuanya berujung pada kekerasan yang berbasis pada gender. Untuk saat ini juga lansia masih didominasi oleh kaum perempuan. Keadaan lingkungan di pondok lansia ini seperti masih memiliki udara yang segar walaupun keadaannya tidak bersih sekali. Menurut salah satu perawat, mengurus lansia ini butuh kesabaran karena sifat para lansia yang sering kembali seperti anak kecil, tapi ia juga menuturkan terkadang juga terhibur dengan tingkah lucu para lansia. Ia telah 3 tahun bekerja menjadi perawat disana, ia menambahkan bahwa pada usia yang telah lanjut memang banyak dari mereka yang terkena penyakit degenerative, umunya mereka menderita stroke, hipertensi, diabetes dan osteoporosis. Namun, juga banyak dari mereka yang masih sehat segar bugar namun menderita peurunan pendengaran dan daya ingat.

Untuk program kegiatan yang dilakukan disana tidak tentu, sebelum melangsungkan kegiatan mereka melihat terlebih dahulu bagaimana kondisi daripada lansia tersebut. Hal ini dikarenakan terkadang saat mereka diajak untuk jalan-jalan pagi berkeliling pondok lansia bagi mereka yang mampu saja karena tidak semua lansia mampu untuk berjalan dalam jarak yang sedikit jauh. Selain itu mereka juga terkadang diajak untuk senam peregangan otot mereka untuk kesehatan sendi-sendi tulang mereka, tidak jarang pula terkadang ada donator yang mengadakan syukuran pula dan mengadakan acara pengajian yang juga melibatkan mereka para lansia. Umunya setiap 2x dalam sebulan mereka dijenguk oleh keluarga mereka. kegiatan mereka hanya sekedar mengisi waktu luang saja agar tidak bosan dan agar mereka tetap merasa bisa produktif di masa tuanya. Untuk menjaga agar mereka tetap dalam keadaan produktif maka mereka biasanya diajarkan menyulam dan membuat taplak meja dari bahan rajutan. Walaupun ada beberapa yayasan ataupun organisasi dengan beberapa program serta kebijakan yang dibuat, diambil dan dilaksanakan oleh berbagai belah pihak ini mereka tetap memiliki tujuan yang sama, yaitu terwujudnya kenyamanan secara fisik dan psikologis para lansia ini di Kota Malang dalam keikutsertaannya dalam pembangunan nasional.

Pertumbuhan lansia yang semakin pesat ini juga berhubungan dengan adanya Asumsi dasar teori kependudukan oleh Karl Marx dan Fried Engels ini ialah bahwa tekanan penduduk yang terdapat disuatu negara bukanlah tekanan penduduk terhadap bahan makanan, tetapi tekanan penduduk terhadap kesempatan kerja. Oleh sebab itu pesatnya pertumbuhan penduduk usia lanjut dari tahun ke tahun di Indonesia tidak selalu akan menjadi beban dalam keluarga, masyarakat, bahkan negara atau menjadi penghambat dalam pembangunan yang sedang berjalan. Marx menekankan bahwa kemiskinan terjadi bukan disebabkan karena pertumbuhan penduduk yang terlalu cepat, tetapi kesalahan masyarakat itu sendiri. Seperti yang sudah dilakukan di Kota Malang saat ini untuk menghadapi dampak pertumbuhan penduduk terutama di usia lajut di masa depan yang semakin meningkat tersebut dengan cara meningkatkan pemberdayaan para lansia.

Pemberdayaan yang dilakukan dengan kebijakan ramah lansia ini melalui yayasan, komunitas, dan organisasi agar lansia mampu berkontribusi serta bermanfaat bagi masyarakat. Sehingga usia tua tidak akan menghalangi seseorang untuk bermanfaat bagi orang 
lain. Walaupun mereka mengalami penurunan secara fisik namun pengalaman dan jaringan mereka dalam banyak hal ini menjadi kelebihan yang mereka miliki sehingga bisa dikembangkan dan diperdayakan yang akan menjadi aset berharga bagi komunitas, keluarga, bahkan negara dalam aspek sosial ekonomi.

Marx juga memiliki pandangan jika semakin tinggi tingkat populasi manusia, semakin tinggi produktifitasnya, jika teknologi tidak menggantikan tenaga manusia sehingga tidak perlu menekan jumlah kelahirannya. Sehingga semakin banyak manusia semakin tinggi produk yang dihasilkan, jadi tidak perlu diadakan pembatasan penduduk. Hal ini dapat dilihat pada salah satu program yang ada di dalam Organisasi Karang weda yaitu dengan melatih lansia harus mampu memanfaatkan pekarangan rumahnya dengan Getari (Gerakan Tanam Mandiri) yakni menanam sayur, cabe, toga, obat tradisional sehingga dapat bermanfaat bagi diri sendiri dan juga bagi orang-orang disekitarnya.

Tujuan utama dari adanya yayasan, organisasi, dan komunitas ini adalah agar penduduk lansia merasa tetap hidup dengan menumbuhkan semangat hidup diusia mereka untuk tetap produktif menjalani kegiatan sesuai dengan kemampuan mereka. Sehingga mereka tidak akan merasakan kesepian, ketidaknyamanan atau bahkan stress saat mereka dalam lingkungan keluarga, masyarakat, dan negara karna mereka merasa menjadi beban bagi orang lain dengan cara tetap produktif diusia lanjut.

Dapat dikatakan bahwa Lansia disadari atau tidak juga ikut andil dan berpartisipasi dalam proses pembangunan. Peran penduduk usia lanjut sangat signifikan. Secara tidak langsung lansia ikut membangun sumber daya manusia (SDM) masyarakat muda saat ini baik di lingkungan masyarakat atau juga lingkungan keluarga. Pengetahuan, pengalamannya dan kearifannya dalam bertindak dan berfikir menjadi kelebihan mereka dalam membangun SDM masa depan. Sehingga mereka dapat mewariskan pengalaman, tindakan yang sesuai dengan norma-norma yang ada dengan agama dan budaya yang sesuai dengan UU yang ada. Sehingga dari generasi ke generasi akan terus bersambung secara estafet yang tak akan putus.

Walaupun saat ini memasuki era Globalisasi dengan kemajuan tekhnologi yang pesat dan tidak dapat dipungkiri bahwa generasi muda lebih mahir dalam hal tekhnologi namun tidak berarti lansia tidak bisa berkontribusi dalam membangun generasi muda. Justru dengan semakin majunya perkembangan tanpa batas ini maka mereka (para lansia) akan bebahaya jika tidak mengambil peran, mereka dapat membangun SDM melalui budaya, akhlak, dan etika yang baik untuk generasi masa depan. Jika lansia tidak ikut berperan dalam membangun SDM di era yang maju seperti sekarang ini maka akan mengancam keutuhan bangsa dan negara di masa depan.

Sehingga seperti yang dikatakan oleh Marx bahwa tingginya pertumbuhan penduduk akan menghasilkan produktifitas yang tinggi pula. Tingginya angka penduduk dalam usia lanjut tidak akan menjadi beban dalam keluarga, masyarakat, bahkan negara jika mereka diberdayakan dan diperlakukan dengan baik. Pengalaman, kearifan, jaringan, dan kreatifitas mereka dalam bertindak dan berfikir menjadi kelebihan yang akan menjadi aset berharga bagi lingkungan mereka dan juga bagi pembangunan nasional. Kelebihan yang sudah ada dalam diri mereka dapat diwariskan pada generasi muda untuk menghasilkan Sumber Daya Manusia yang lebih baik. Menciptakan keadaan nyaman dan tenang akan berdampak baik dalam psikis mereka dalam menumbuhkan semangat mereka untuk tetap berproduksi diusia lanjut. Kegiatan produktifitas yang mereka hasilkan memang tidak semaksimal saat mereka masih 
diusia produktif, namun mereka sudah dapat menghasilkan sesuatu dalam usia lanjut sudah merupakan sesuatu kemajuan yang luar biasa. Seperti hanya merawat pekarangan, merajut, mengolah sampah, dan lain-lain yang dapat bermanfaat bagi diri sendiri dan bagi orang lain.

\section{Simpulan}

Menjadi tua merupakan suatu kondisi dalam proses alami (biologi) manusia mengalami perubahan secara fisik, mental, dan juga sosial sebagai akibat bertambahnya usia. Tingginya tingkat penduduk dengan usia lanjut dalam suatu negara dapat menjadi suatu yang memiliki dampak positik namun juga memiliki dampak negatif pada proses pembangunan. Dampak yang akan muncul jika tingginya penduduk usia lanjut terus meningkat ini tergantung pada bagaimana kita sebagai generasi penerus bangsa saat ini menyikapinya. Lansia bisa menjadi beban dan juga bisa menjadi aset berharga bagi negara dalam pembangunan nasional.

Malang merupakan kota dengan penduduk usia lanjut yang cukup tinggi, namun karna masyarakat didalamnya terutama pemerintahan sadar akan pentingnya menjadi ramah pada lansia maka Malang merupakan salah satu kota yang akan mendapat apresiasi best partice di tahun 2030. Ada beberapa yayasan, organisasi, dan komunitas ramah lansia di kota Malang. Tidak hanya itu tetapi juga ada beberapa kebijakan dari pemerintah daerah sendiri yang di khususkan untuk para lansia, seperti loket pelayanan publik khusus lansia dan pembuatan UU perda yang dibuat khusus untuk lansia.

Walaupun banyak kebijakan dan yayasan yang ada di kota Malang dengan programprogram yang beragam namun mereka memiliki tujuan yang sama, yaitu terwujudnya kenyamanan secara fisik dan psikologis para lansia ini di Kota Malang agar tetap produktif dan berperan dalam pembangunan nasional. Sehingga Tingginya angka penduduk dalam usia lanjut tidak akan menjadi beban dalam keluarga, masyarakat, bahkan negara jika mereka diberdayakan dan diperlakukan dengan baik. Pengalaman, kearifan, jaringan, dan kreatifitas mereka dalam bertindak dan berfikir menjadi kelebihan yang akan menjadi aset berharga bagi lingkungan mereka dan juga bagi pembangunan nasional. Kelebihan yang sudah ada dalam diri mereka dapat diwariskan pada generasi muda untuk menghasilkan Sumber Daya Manusia yang lebih baik untuk bekal di masa depan.

Setiap manusia pasti akan menjadi tua dalam proses pertumbuhannya. Tua merupakan sesuatu yang tidak bisa dihindari. Lansia memang sudah memiliki penurunan pada fungsi organ tubuhnya namun semangat sehat jasmani dan rohaninya tidak akan menurun. Banyak sekali lansia disekitar kita yang berharap diperhatikan dan dianggap. Mereka akan merasa kesepian dan menjadi beban untuk orang sekitarnya. Jika mereka tidak mendapatkan kenyamanan secara fisik dan psikis maka mereka akan cepat menjadi stress.

Membuat mereka tinggal di panti dan berharap mereka menjadi terawat dan mendapat lingkungan sosial yang nyaman itu bukan sesuatu solusi. Mereka akan merasa semakin jauh dengan keluarga dan lingkungan sosialnya. Hal itu tidak akan membuat mereka bahagia dan tidak akan membuat nyama. Cukup dengan kita percaya dan ramah atas kemampuan mereka itu akan menumbuhkan semangat hidup mereka untuk tetap berproduksi diusia lanjut mereka. Perdayakan mereka sesuai kemampuan mereka maka mereka akan melakukannya dengan sepenuh hati.

Tingginya pertumbuhan penduduk usia lanjut tidak selalu menjadi beban negara, tergantung bagaiana kita sebagai generasi penerus bangsa menyikapinya. Mereka memiliki 
Jurnal Integrasi dan Harmoni Inovatif Ilmu-Ilmu Sosial (JIHI3S), 1(2), 2021, 45-53

kelebihan yang tidak kita (generasi muda) miliki sehingga buat mereka menjadi aset berharga negara bukan beban negara. Perlakukan para lansia dengan ramah dan baik karna suatu saat kita juga akan menjadi seperti mereka yang ingin dianggap dan diperlakukan dengan baik pula. Karna apa yang kita tanam maka itu yang akan kita tuai nanti.

\section{Daftar Rujukan}

Berita Jatim. (2018). Pemerintah Malang Mulai Merancang Perda LAnsia. Malang.

Bogdan, R.C. dan Biklen, S.K. (1982). Qualitativ Research For Education An Introduction to Theory and Methods. Boston: Allyn and Bacon, Inc.

Fitzpatrick, Kevin and Mark LaCory. (2000). Unhealthy Places, The Ecology of Risk in the Urban Lanscape. Routledge. New York.

Katalog BPS. (2013). Proyeksi Penduduk Indonesia 2010-2035. Jakarta: BPS.

Lansia RI.com

malangkab.bps.go.id

Marshall, C. Dan Rossman, G.B. (1989). Designing Qualitative Research. New burry Park, California: Sage Publication.

Media Center Malang. (2012). Lansia Harus Tetap Ceria. Malang.

Nugroho, Abikusno. (2013). Kelanjutan Sehat Menuju Masyarakat Sehat Untuk Segala Usia. Jakarta: Buletin Jendela Data dan Informasi Kesehatan, Semester I, 2013.

Turana. (2013). Simulasi Otak pada Kelompok Lansia di Komunitas: Buletim Jendela Data dan Informasi Kesehatan.

Tribun News. (2017). Pemprov Jatim Akan Perbanyak Loket Khusus Lansia di Kantor Pelayanan Publik. Surabaya.

UU Republik Indonesia Nomor 13 tahun 2008.

_.. (2007). Kota Ramah Lansia Global (Terjemahan WHO). Komnas. 